\title{
PEMBERIAN KOMBINASI 2,4-D DAN KINETIN TERHADAP INDUKSI PROTOCORM LIKE BODIES (PLB) ANGGREK Grammatophyllum scriptum SECARA IN VITRO
}

\author{
Atika Okta Melisa \\ INSTITUT AGAMA ISLAM NEGERI KUDUS \\ Email: melisabio16@gmail.com
}

\begin{abstract}
ABSTRAK
Grammathopyllum scriptum merupakan salah satu anggrek yang mempunyai nilai ekonomis tinggi. Anggrek ini tersebar di wilayah Papua dan Sulawesi. Tanaman anggrek sulit untuk dikembangbiakan secara alami, termasuk G. scriptum, sehingga dibutuhkan teknik kultur jaringan untuk membantu pelestariannya. Tujuan penelitian ini adalah untuk mengetahui pengaruh pemberian kombinasi hormon 2,4-D dan kinetin terhadap induksi protocorm like bodies (plb) anggrek G. scriptum secara in vitro. Metode penelitian yang digunakan adalah rancangan acak lengkap (RAL) dengan satu faktor perlakuan yaitu kombinasi 2,4-D (2mg/L, $4 \mathrm{mg} / \mathrm{L}, 6 \mathrm{mg} / \mathrm{L}, 8 \mathrm{mg} / \mathrm{L}, 10 \mathrm{mg} / \mathrm{L})$ dan kinetin $(1 \mathrm{mg} / \mathrm{L}$ dan $2 \mathrm{mg} / \mathrm{L})$ serta kontrol (MS0) dengan 3 ulangan. Data yang diambil berupa data kualitatif dengan mengamati morfologi $p l b$, dan data kuantitatif dengan menghitung panjang $p l b$. Hasil penelitian ini menunjukkan bahwa pemberian kombinasi hormon 2,4-D dan kinetin tidak berpengaruh nyata terhadap pertumbuhan panjang $p l b .42,5 \%$ eksplan membentuk plb. $P l b$ terbentuk pada konsentrasi $2 \mathrm{mg} / \mathrm{L} \mathrm{2,4-D} \mathrm{dan} 1 \mathrm{mg} / \mathrm{L}$ kinetin hingga konsentrasi $6 \mathrm{mg} / \mathrm{L}$ 2,4-D dan $1 \mathrm{mg} / \mathrm{L}$ kinetin.
\end{abstract}

Kata kunci : Grammathopyllum scriptum, 2,4-D, kinetin, protocorm like bodies.

\begin{abstract}
Grammathopyllum scriptum is one of orchid which has a high economic value. This orchid has spread in Papua and Sulawesi. Orchid is difficult to bred naturally, included G. scriptum so tissue culture techniques are needed to help its preservation. The aims of this research are to study the adduction of the combination of 2,4-D and kinetin to protocorm like bodies (plb) of Grammathopyllum scriptum explants in vitro. The method used completely randomized design (CRD) with two factors, the concentration of growth hormone treatment of 2,4-D (2 mg/L, $4 \mathrm{mg} / \mathrm{L}, 6 \mathrm{mg} / \mathrm{L}, 8 \mathrm{mg} / \mathrm{L}$ and $10 \mathrm{mg} / \mathrm{L})$, kinetin $(1 \mathrm{mg} / \mathrm{L}$ and $2 \mathrm{mg} / \mathrm{L})$ and controls (MSO) with 3 replications. This research used a
\end{abstract}


qualitative data by observing the morphology of plb and shoots as well as quantitative data by calculating the percentage of plb and shoots. The results of this study showed that $42.5 \%$ explants forming PLB, $3.04 \%$ and $45.46 \%$ forming buds forming callus. The callus was formed at the same time. Callus began to form in combination with a growth hormone concentration of $6 \mathrm{mg} / \mathrm{L} \mathrm{2,4-D}$ and 2 $\mathrm{mg} / \mathrm{L}$ kinetin up to a concentration of $10 \mathrm{mg} / \mathrm{L} 2,4-D$ and $2 \mathrm{mg} / \mathrm{L}$ kinetin. PLB was formed at a concentration of $2 \mathrm{mg} / \mathrm{L} 2,4-D$ and $1 \mathrm{mg} / \mathrm{L}$ kinetin concentrations up to $6 \mathrm{mg} / \mathrm{L} \mathrm{2,4-D}$ and $1 \mathrm{mg} / \mathrm{L}$ kinetin. In the media treatment of $4 \mathrm{mg} / \mathrm{L} \mathrm{2,4-D}$ and 2 mg/L kinetin formed buds.

Key words: Grammathopyllum scriptum, 2,4-D, Kinetin, protocorm like bodies, callus

\section{PENDAHULUAN}

Indonesia merupakan negara yang memiliki keanekaragaman hayati terbesar di dunia, salah satunya adalah keanekaragaman anggrek. Salah satu contohnya adalah Grammatophyllum scriptum, di Indonesia G. scriptum tersebar di wilayah Papua dan Sulawesi (Sulistiarini, 2008). Menurut Sulistiarini (2008) anggrek G. scriptum dapat berpotensi sebagai tanaman hias dan induk silangan. G.scriptum memiliki warna bunga yang indah, selain itu, juga dapat digunakan sebagai obat pada penyakit beri-beri, sariawan dan disentri. Berdasarkan manfaat dan keindahan bunganya, G. scriptum banyak dicari dan diburu oleh aktivitas manusia yang akhirnya menyebabkan kelangkaan G.scriptum. Hal ini ditambah dengan sulitnya perkembangbiakan secara alami di alam, oleh karena itu dibutuhkan teknik kultur jaringan untuk membantu pelestariaannya.

Menurut Zulkarnain (2009) kultur jaringan merupakan suatu metode untuk mengisolasi bagian dari tanaman (protoplasma, sel, jaringan dan organ), serta ditumbuhkan dalam kondisi aseptik sehingga bagian-bagian tersebut dapat memperbanyak diri dan beregenerasi menjadi tanaman utuh kembali. Teknik kultur jaringan berkembang pesat setelah ditemukannya zat pengatur tumbuh yang berfungsi untuk membantu dan mempercepat pertumbuhan tanaman kultur. Arah perkembangan kultur ditentukan oleh interaksi dan perimbangan antara zat pengatur tumbuh endogen dengan zat pengatur tumbuh eksogen. Pemakaian zat pengatur tumbuh asam 2,4-D biasa digunakan dalam waktu yang singkat, antara 
2-4 minggu karena merupakan auksin kuat, artinya auksin ini tidak dapat diuraikan di dalam tubuh tanaman (Fitrianti, 2006). Kinetin merupakan zat pengatur tumbuh yang mempunyai aktivitas tinggi dalam memacu pembelahan sel. Pemakaian kombinasi zat pengatur tumbuh tersebut diharapkan dapat memicu perubahan terhadap eksplan pada kultur jaringan anggrek G. scriptum.

Penelitian tentang pengaruh kombinasi hormon 2,4-D dan kinetin terhadap induksi protocorm like bodies (plb) G. Scriptum dalam media MS belum pernah dilakukan, oleh karena itu, penelitian ini bertujuan untuk mengetahui pengaruh dari pemberian kombinasi hormon 2,4-D (auksin) dan kinetin (sitokinin) terhadap eksplan G. scriptum.

\section{METODE PENELITIAN}

Penelitian ini dilaksanakan di Laboratorium Biologi FMIPA dan Laboratorium Kultur Jaringan Sub Lab Biologi, Laboratorium Pusat MIPA Universitas Sebelas Maret Surakarta. Penelitian ini dilaksanakan selama 7 bulan, Februari-September 2011.

\section{Sterilisasi alat}

Alat yang digunakan dalam penelitian ini adalah botol kultur, pinset, scalpel, cawan petri, dan pisau. Alat dicuci menggunakan sabun sampai bersih kemudian dikeringkan, setelah itu alat disterilisasi menggunakan autoklaf pada suhu $121^{\circ} \mathrm{C}$ dengan tekanan 1,5 atm selama 20 menit.

\section{Pembuatan Larutan Stok}

Pembuatan larutan stok bertujuan untuk memudahkan dalam pembuatan media. Larutan stok yang dibuat adalah larutan stok zat pengatur tumbuh. Larutan stok 2,4-D dibuat $20 \mathrm{mg} / \mathrm{L}$ dan kinetin $5 \mathrm{mg} / \mathrm{L}$. Zat pengatur tumbuh 2,4-D ditimbang sebanyak $20 \mathrm{mg}$ dan dilarutkan dalam alkohol (beberapa tetes saja) dan diencerkan dengan aquades sebanyak $1 \mathrm{~L}$. Kinetin ditimbang $5 \mathrm{mg}$ dan dilarutkan dalam alkohol (beberapa tetes saja) dan diencerkan dengan aquades sebanyak $1 \mathrm{~L}$. Penyimpanan larutan stok zat pengatur tumbuh disimpan di dalam lemari es untuk menjaga agar tidak rusak.

\section{Pembuatan Media Dasar}


Serbuk media MS (Coisson Labs) sebesar 4,43 g dilarutkan dengan aquades, selanjutnya ditambah gula $40 \mathrm{~g}$ dan dilarutkan dalam 1 liter air, kemudian diukur pH 5,8. Selanjutnya ditambahkan agar 12 g. Larutan kemudian dimasak sampai mendidih. Larutan dimasukkan ke dalam botol kultur, ditutup dengan aluminium foil kemudian disterilisasi menggunakan autoclaf dengan suhu $121^{\circ} \mathrm{C}$, tekanan 1,5 atm selama 20 menit, kemudian didinginkan.

\section{Pembuatan Media Perlakuan}

Pembuatan media perlakuan dilakukan dengan cara mencampurkan media dasar dengan zat pengatur tumbuh 2,4-D dan kinetin. Komposisi dari masingmasing senyawa ditentukan dengan menggunakan persamaan sebagai berikut :

$\mathrm{N}_{1} \times \mathrm{V}_{1}=\mathrm{N}_{2} \times \mathrm{V}_{2}$

Keterangan :

- $\mathrm{N}_{1}$ : Konsentrasi stok zat pengatur tumbuh

$-\mathrm{V}_{1}$ : volume stok zat pengatur tumbuh

- $\mathrm{N}_{2}$ : konsentrasi zat pengatur tumbuh yang akan dibuat

$-\mathrm{V}_{2}$ : Volume total

\section{Penanaman}

Planlet G. scriptum dipotong pada bagian hipokotil, kira-kira $2-3 \mathrm{~cm}$. Pemotongan dilakukan dengan menggunakan scalpel steril. Eksplan yang akan ditanam dalam media kultur, diambil dengan menggunakan pinset dan ditanam dalam media perlakuan. Perubahan yang terjadi, diamati selama 10 minggu.

\section{Pengambilan Data}

Pengambilan data dilakukan setelah 10 minggu. Data yang digunakan adalah data morfologi dan anatomi. Data morfologi meliputi warna $p l b$, perubahan yang terjadi pada eksplan serta eksplan yang mampu membentuk plb. Data anatomi diamati dengan membuat preparat irisan plb, setelah dilakukan pengamatan morfologi.

a. Pengambilan Data Morfologi

Pengamatan morfologi dilakukan 3 hari sekali selama 10 minggu. Pengamatan dilakukan dengan menggunakan kaca pembesar, mikroskop, timbangan dan kamera. 
b. Pengambilan Data Anatomi

Pengambilan data anatomi dengan cara membuat preparat anatomi menggunakan teknik embedding section dan pewarnaan menggunakan safranin 1\%. Tahapan pembuatan preparat dengan embedding section adalah sebagai berikut ini: fiksasi (FAA), pencucian, dehidrasi, infiltrasi, penyelubungan (parafin), pengirisan, perekatan, pewarnaan (safranin), penutupan dan pelabelan. Analisis Data

Data kualitatif dianalisis secara deskriptif, peubah yang diamati dalam penelitian ini meliputi, eksplan yang mampu membentuk plb dan warna dari $p l b$. Mulai minggu ke-berapa mulai terjadi perubahan. Data kuantitatif meliputi, prosentase eksplan membentuk $p l b$ dan panjang $p l b$. Data kuantitatif panjang diuji dengan menggunakan One Way ANOVA.

\section{HASIL DAN PEMBAHASAN}

Ada perubahan terhadap eksplan yang ditanam baik pada kontrol maupun pada media perlakuan (Tabel. 1). Setiap eksplan mengalami perubahan yang berbeda-beda, setelah 10 minggu, variasi perubahan eksplan terlihat jelas. Ada sebagian yang tumbuh $p l b$ dan sebagian tumbuh tunas.

Perubahan yang terjadi terhadap eksplan bervariasi, untuk MS0 perubahan terjadi pada minggu ke-7 dan pertumbuhan paling cepat adalah pada media D2K1,D2K2, D4K1, D4K2 dan D6K1 yaitu pada minggu ke-3. Media D6K2, D8K1, D8K2, D10K1 dan D10K2 mulai ada perubahan pada minggu ke-8, pertumbuhan yang bervariasi ini dimungkinkan karena pengaruh dari kombinasi hormon eksogen yang diberikan dan hormon eksogen tersebut berinteraksi dengan hormon endogen yang terdapat di dalam eksplan. Eksplan yang diambil merupakan batang hipokotil yang masih aktif membelah (meristematik).

Menurut Dorusposari (2003) dalam Wijayani,dkk (2007) pertumbuhan protocorm like body tanaman anggrek terbagi menjadi 5 kategori, yaitu (1) plb berwarna putih kekuningan, transparan, kompak dan keras, (2) plb berwarna kehijauan, (3) plb dengan primordia daun tunggal dan berwarna hijau muda, (4) tunas yaitu $p l b$ dengan satu atau dua calon daun dengan lamina yang jelas, 
berwarna hijau tua, (5) planlet. Penelitian ini menunjukkan sampai kategori ketiga yaitu tunas.

Tabel 1. Data Prosentase Pembentukan $p l b$ dan tunas

\begin{tabular}{ccccc}
\hline Jenis & \multicolumn{3}{c}{ Prosentase Pembentukan } & Mulai tumbuh \\
\cline { 2 - 4 } Media & $\begin{array}{c}\text { plb } \\
\text { putih }\end{array}$ & $p l b$ & Tunas & \\
\hline MS0 & - & $100 \%$ & - & Minggu ke-7 \\
D2K1 & $33,3 \%$ & $66,7 \%$ & - & Minggu ke-3 \\
D2K2 & $33,3 \%$ & $66,7 \%$ & - & Minggu ke-3 \\
D4K1 & - & $100 \%$ & - & Minggu ke-3 \\
D4K2 & - & $66,7 \%$ & $33,3 \%$ & Minggu ke-3 \\
D6K1 & $33,3 \%$ & $33,3 \%$ & - & Minggu ke-3 \\
D6K2 & $33,3 \%$ & - & - & Minggu ke-8 \\
D8K1 & $100 \%$ & - & - & Minggu ke-8 \\
D8K2 & $100 \%$ & - & - & Minggu ke-8 \\
D10K1 & $100 \%$ & - & - & Minggu ke-8 \\
D10K2 & $66,7 \%$ & - & - & Minggu ke-8 \\
\hline
\end{tabular}

Keterangan:

MS0 : media tanpa penambahan hormon

D2K1 : media dengan penambahan $2 \mathrm{mg} / \mathrm{L}$ 2,4-D dan $1 \mathrm{mg} / \mathrm{L}$ kinetin.

D2K2 : media dengan penambahan $2 \mathrm{mg} / \mathrm{L}$ 2,4-D dan $2 \mathrm{mg} / \mathrm{L}$ kinetin.

D4K1 : media dengan penambahan $4 \mathrm{mg} / \mathrm{L} \mathrm{2,4-D} \mathrm{dan} 1 \mathrm{mg} / \mathrm{L}$ kinetin.

D4K2 : media dengan penambahan $4 \mathrm{mg} / \mathrm{L}$ 2,4-D dan $2 \mathrm{mg} / \mathrm{L}$ kinetin.

D6K1 : media dengan penambahan $6 \mathrm{mg} / \mathrm{L}$ 2,4-D dan $1 \mathrm{mg} / \mathrm{L}$ kinetin.

D6K2 : media dengan penambahan $6 \mathrm{mg} / \mathrm{L} \mathrm{2,4-D} \mathrm{dan} 2 \mathrm{mg} / \mathrm{L}$ kinetin.

D8K1 : media dengan penambahan $8 \mathrm{mg} / \mathrm{L}$ 2,4-D dan $1 \mathrm{mg} / \mathrm{L}$ kinetin.

D8K2 : media dengan penambahan $8 \mathrm{mg} / \mathrm{L} \mathrm{2,4-D} \mathrm{dan} 2 \mathrm{mg} / \mathrm{L}$ kinetin.

D10K1 : media dengan penambahan $10 \mathrm{mg} / \mathrm{L}$ 2,4-D dan $1 \mathrm{mg} / \mathrm{L}$ kinetin.

D10K2 : media dengan penambahan $10 \mathrm{mg} / \mathrm{L}$ 2,4-D dan $2 \mathrm{mg} / \mathrm{L}$ kinetin.

\section{A. Induksi $P l b$ putih}

Eksplan awalnya membentuk tonjolan kecil putih bening di bagian pelukaan mulai pada minggu ke-8 dan pada minggu ke-10 bertambah banyak. Ini disebabkan terjadinya autolisis sel dari sel yang rusak tersebut akan dihasilkan senyawa-senyawa yang akan merangsang pembelahan sel di lapisan berikutnya. Warna $p l b$ putih kekuningan, transparan, kompak dan keras. Pembelahan sel tidak terjadi pada semua sel eksplan, tetapi hanya sel perifer yang mengalami pembelahan terus-menerus, sedangkan sel-sel di tengah tetap. Hal ini dimungkinkan karena ketersediaan oksigen yang lebih tinggi, keluarnya gas $\mathrm{CO}_{2}$, 
ketersediaan hara yang lebih banyak, penghambat yang bersifat folatik lebih cepat menguap dan cahaya (Gunawan, 1988).

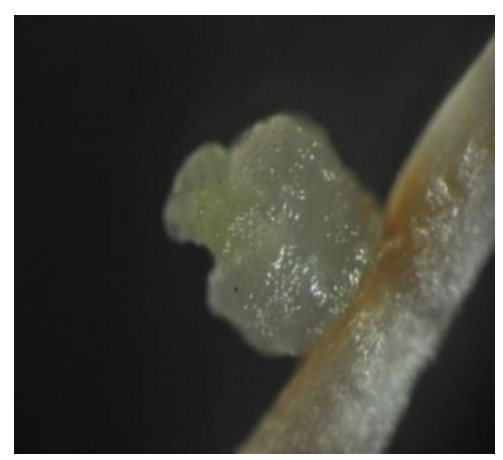

Gambar 1. Plb putih yang terbentuk pada media D6K2

Tabel 1. menunjukkan bahwa untuk induksi plb putih pada anggrek $G$. scriptum terjadi pada media MS dengan penambahan 2,4-D dengan konsentrasi yang jauh lebih tinggi dibanding konsentrasi kinetin. Diketahui bahwa eksplan yang mulai terbentuk plb putih adalah pada media dengan penambahan hormon 2,4-D sebesar $6 \mathrm{mg} / \mathrm{L}$ dan kinetin sebesar 2mg/L, hingga media dengan penambahan 2,4-D sebesar $10 \mathrm{mg} / \mathrm{L}$ dan kinetin sebesar $2 \mathrm{mg} / \mathrm{L}$. Menurut Smith (1992) konsentrasi auksin yang rendah akan meningkatkan pembentukan tunas adventif, sedangkan auksin dengan konsentrasi tinggi akan merangsang pembentukan kalus dan menekan morfogenesis.

\section{B. Induksi Protocorm Like Bodies (plb)}

Protocorm adalah bentukan bulat yang siap membentuk pucuk dan akar sebagai awal perkecambahan pada biji yang tidak mempunyai endosperm. Perkembangannya di alam perlu berasosiasi dengan mikoriza (Gunawan, 1988). Protocorm like bodies ( $p l b$ ) adalah protocorm yang sudah tumbuh tapi masih belum terdeferensiasi dengan sempurna. Menurut Zulkarnain (2009), plb merupakan bagian vegetatif dari sejumlah anggrek di dalam kultur yang membentuk struktur yang menyerupai protocorm berbentuk bulat dan mengkilap, yang dapat diperbanyak secara tak terbatas atau dapat diinduksi untuk meregenerasikan tanaman lengkap. 


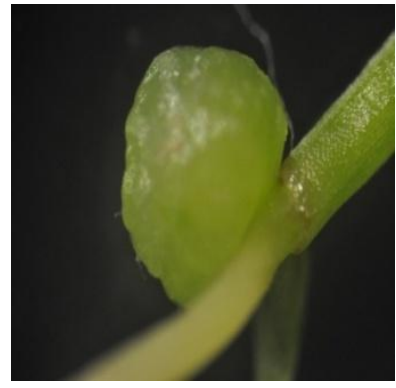

a.

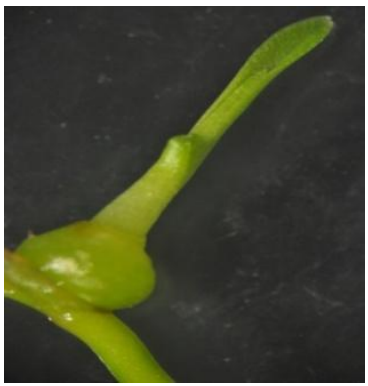

b.

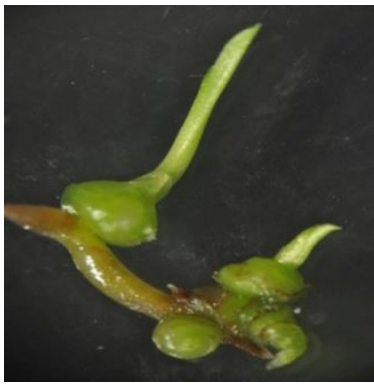

c.

Gambar 2. a. Plb b. Plb dengan inisiasi daun c. Tunas

Tanda-tanda biji anggrek berkecambah ialah biji kelihatan berwarna kuning hijau dan membentuk bulatan-bulatan seperti gelembung yang disebut dengan protocorm like bodies (plb). Pada penelitian Abbas et al., (2007) perkembangan protocorm diawali dengan perubahan warna benih, biji membengkak, bentuk bulat, dan protocorm sebelum berdeferensiasi menjadi organ, dan selanjutnya membentuk protocorm dengan inisiasi daun.

Kalimuthu et al. (2007), menyatakan bahwa dalam produksi bibit anggrek Oncidium spp., dari biji ada beberapa tahapan perkecambahan yaitu, terbentuknya protocorm, kulit biji (testa) pecah dan akar terbentuk selanjutnya tahap inisial tunas dan pengembangan bibit. Pada penelitian ini, eksplan yang digunakan adalah hipokotil, jadi tidak ada tahapan pecahnya testa, protocorm yang terbentuk disebut dengan protocorm like body (plb), selanjutnya inisiasi tunas dan inisiasi akar terbentuk. Pekembangan selanjutnya akan menjadi individu yang utuh.

Penelitian ini terdapat eksplan yang tumbuh menjadi $p l b$, eksplan anggrek G.scriptum tersebut langsung mengalami proses organogenesis. Menurut Gunawan (1988) organogenesis merupakan proses terbentuknya organ-organ seperti pucuk dan akar. Protocorm like bodies ini mulai muncul pada minggu ke-3 pada media D2K1, D2K2, D4K1, D4K1 dan D6K1, serta minggu ke-7 pada media MS0. Munculnya $p l b$ diawali dengan tonjolan bulat putih kehijauan yang lamakelamaan akan bertambah besar dan setelah 10 minggu mulai memanjang membentuk inisiasi daun dan jika pengamatan dilakukan lebih lama maka lama kelamaan akan membentuk tunas dan inisisasi akar. 


\section{Pertumbuhan Tunas}

Tunas terbentuk jika hormon sitokinin lebih tinggi dibanding hormon auksin, meski dalam media perlakuan hormon eksogen yang diberikan lebih tinggi konsentrasi hormon auksin, namun dapat terbentuk tunas, ini mungkin dikarenakan oleh hormon sitokinin endogen cukup tinggi sehingga meski ditambah hormon auksin eksogen tinggi, namun masih belum mampu untuk mengimbangi hormon sitokinin endogen dari G. Sriptum. Smith (1992) menyatakan bahwa kadar sitokinin endogen lebih tinggi dibanding dengan kadar auksin akan menyebabkan terbentuknya tunas.

Media yang menghasilkan tunas hanya pada media MS dengan pemberian 2,4-D $4 \mathrm{mg} / \mathrm{L}$ + kinetin $2 \mathrm{mg} / \mathrm{L}$ (D4K2). Ada 4 tunas yang terbentuk (D4K2). Pertumbuhan tunas ini adalah pertumbuhan lanjut dari plb kemudian setelah 10 minggu sudah terlihat tunas. Pada media D4K2 terbentuk lebih banyak tunas, ini dikarenakan media dengan penambahan hormon eksogen 2,4-D 4 mg/L + kinetin $2 \mathrm{mg} / \mathrm{L}$ cocok untuk menginduksi terbentuknya tunas melalui organogenesis eksplan.

Awal pertumbuhan tunas diawali dengan adanya bulatan kecil putih kehijauan pada minggu ke-3 dan selanjutnya bulatan kecil tersebut bertambah besar dan membentuk $p l b$. Plb mengalami pemanjangan dan akhirnya terbentuk tunas dan sudah mulai terlihat inisiasi akar.

\section{Pengamatan Anatomi}

Pada penampang membujur plb terlihat adanya inisiasi pucuk dan inisiasi daun, terlihat juga benda-benda ergastik berupa Ca-oksalat berbentuk jarum. Menurut Sutriyan (1992). Benda ergastik dalam sel yang bersifat padat umumnya berbentuk butiran atau kristal yang biasanya terbentuk sebagai hasil akhir dari metabolisme dalam tumbuh-tumbuhan. Kristal Ca-oksalat termasuk dalam benda ergastik padat dan biasanya terdapat dalam sel korteks namun tidak jarang ditemukan dalam sel parenkim floem dan parenkim xilem. 


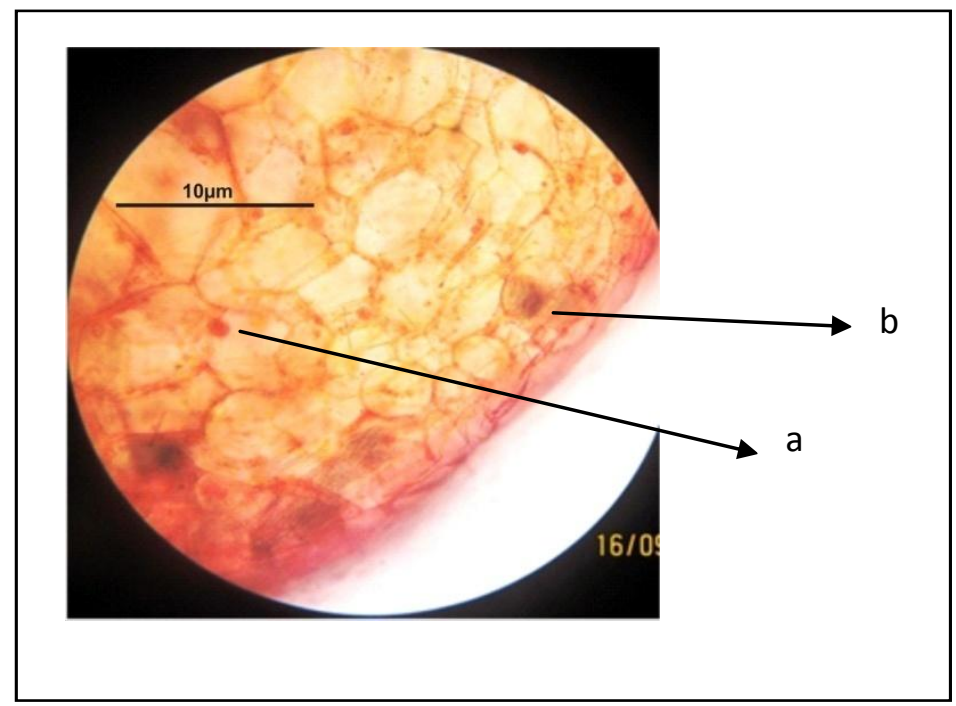

Gambar 3. Potongan membujur plb anggrek G.scriptum media pada D2K2 umur 10 minggu dengan perbesaran 400X; a. Inti sel; b. Ca-oksalat

Kristal Ca-oksalat ada beberapa bentuk, yang ditemukan dalam anatomi hasil penelitian ini berbentuk jarum dan rafida yang merupakan kristal bentuk jarum yang letaknya sejajar satu sama lain. Kristal Ca-oksalat umumnya terdapat pada sel parenkim tumbuhan dari jaringan-jaringan lunak yang selnya mengandung lendir dan berdinding tipis, misalnya dalam tanaman monokotiledon.

Pada gambar 3 terlihat adanya Ca-oksalat pada preparat potongan membujur dari $p l b$ yang terbentuk pada media MS dengan penambahan $2 \mathrm{mg} / \mathrm{L}$ 2,4-D dan 2 $\mathrm{mg} / \mathrm{L}$ kinetin. Kristal Ca-oksalat lebih banyak terlihat pada media perlakuan terutama pada bagian inisiasi daun dan tunas.

\section{E. Pertumbuhan Panjang plb dan Tunas}

Pemberian hormon eksogen dapat membantu pertumbuhan eksplan yang awalnya hanya potongan hipokotil, dengan pemberian hormon eksogen yang berupa auksin 2,4-D dan sitokinin kinetin dapat tumbuh menjadi plb dan tunas. Perbedaan pertumbuhan sangat tergantung dengan konsentrasi hormon eksogen yang diberikan ke dalam media. Hasil penelitian ini menunjukkan perbedaan yang terlihat jelas bahwa pertumbuhan plb terbentuk dari MS0 sampai 2,4-D 6 mg/L 
dan $1 \mathrm{mg} / \mathrm{L}$ kinetin. Tunas hanya terbentuk pada hormon 2,4-D dengan konsentrasi $4 \mathrm{mg} / \mathrm{L}$ dan $2 \mathrm{mg} / \mathrm{L}$ kinetin.

Tabel 3. menunjukkan data pertumbuhan plb dan tunas, dan dari tabel 4 . dapat disimpulkan bahwa rata-rata pertumbuhan eksplan paling panjang adalah pada media D6K1 dan diikuti oleh media D4K2. Ini berarti bahwa media D6K1 dan D4K2 memiliki konsentrasi hormon yang cocok untuk pertumbuhan dan perkembangan eksplan. Kedua media ini menghasilkan $p l b$ dan sudah terlihat $p l b$ yang tumbuh dan mulai membentuk calon daun dan selanjutnya akan berdeferensiasi menjadi tanaman baru. Hal ini berarti bahwa anggrek G. scriptum cenderung membentuk protocorm bila diberi hormon eksogen dalam konsentrasi rendah.

Seperti yang disebutkan pada penelitian Meyer et al., (2010), bahwa untuk regenerasi langsung dari $p l b$ menggunakan apex daun Oncidium flexuosum, dalam media hanya ditambah 1,5 $\mu \mathrm{M}$ TDZ (thidiazuron), $80 \%$ eksplan beregenerasi 30 tanaman tiap eksplan. Sebelum berdeferensiasi Grammathopyllum scriptum membentuk protocorm dan protocorm dengan inisiasi daun (Abbas et al., 2011). Medium MS yang diberi zat tambahan (suplemen) dengan konsentrasi yang sesuai dari zat pengatur tumbuh yang ditambahkan akan membantu dalam dalam germinasi biji, produksi $p l b$, multipikasi tunas dan inisiasi akar (Kalimuthu et al., 2007).

Tabel 2. Data pertumbuhan panjang plb putih

\begin{tabular}{cc}
\hline Jenis Media & Rata-rata $(\mathrm{cm})$ \\
\hline D2K1 & 0,3 \\
D2K2 & 0,15 \\
D6K1 & 0,2 \\
D6K2 & 0,2 \\
D8K1 & 0,27 \\
D8K2 & 0,4 \\
D10K1 & 0,2 \\
D10K2 & 0,35 \\
\hline
\end{tabular}

Tabel 3. Data Pertumbuhan panjang $p l b$

\begin{tabular}{cc}
\hline Jenis Media & Rata-rata $(\mathrm{cm})$ \\
\hline MS0 & 0,33
\end{tabular}




\begin{tabular}{lc} 
D2K1 & 0,16 \\
D2K2 & 0,32 \\
D4K1 & 0,5 \\
D4K2 & 0,8 \\
D6K1 & 0,2 \\
\hline
\end{tabular}

Tabel 4. Data Pertumbuhan tunas

\begin{tabular}{cc}
\hline Jenis Media & Rata-rata $(\mathrm{cm})$ \\
\hline $\mathrm{D} 4 \mathrm{~K} 2$ & 1,1 \\
\hline
\end{tabular}

Keterangan:

MS0 : media tanpa penambahan hormon

D2K1 : media dengan penambahan $2 \mathrm{mg} / \mathrm{L}$ 2,4-D dan $1 \mathrm{mg} / \mathrm{L}$ kinetin.

D2K2 : media dengan penambahan $2 \mathrm{mg} / \mathrm{L}$ 2,4-D dan $2 \mathrm{mg} / \mathrm{L}$ kinetin.

D4K1 : media dengan penambahan $4 \mathrm{mg} / \mathrm{L} 2,4-\mathrm{D}$ dan $1 \mathrm{mg} / \mathrm{L}$ kinetin.

D4K2 : media dengan penambahan $4 \mathrm{mg} / \mathrm{L}$ 2,4-D dan $2 \mathrm{mg} / \mathrm{L}$ kinetin.

D6K1 : media dengan penambahan $6 \mathrm{mg} / \mathrm{L}$ 2,4-D dan $1 \mathrm{mg} / \mathrm{L}$ kinetin.

D6K2 : media dengan penambahan $6 \mathrm{mg} / \mathrm{L}$ 2,4-D dan $2 \mathrm{mg} / \mathrm{L}$ kinetin.

D8K1 : media dengan penambahan $8 \mathrm{mg} / \mathrm{L}$ 2,4-D dan $1 \mathrm{mg} / \mathrm{L}$ kinetin.

D8K2 : media dengan penambahan $8 \mathrm{mg} / \mathrm{L} 2,4-\mathrm{D}$ dan $2 \mathrm{mg} / \mathrm{L}$ kinetin.

D10K1 : media dengan penambahan $10 \mathrm{mg} / \mathrm{L} \mathrm{2,4-D} \mathrm{dan} 1 \mathrm{mg} / \mathrm{L}$ kinetin.

D10K2 : media dengan penambahan $10 \mathrm{mg} / \mathrm{L}$ 2,4-D dan $2 \mathrm{mg} / \mathrm{L}$ kinetin.

Ng, Chuam-Yih el al., (2010) mengatakan bahwa pada Paphiopedilum rothschildianum (Orchidaceae) dapat membentuk tunas setelah 16 minggu kultur dalam media 1/2 MS. Pada anggrek Grammathopyllum scriptum hanya membutuhkan waktu 10 minggu dengan menggunakan media MS dengan penambahan zat pengatur tumbuh dengan konsentrasi $4 \mathrm{mg} / \mathrm{L} \mathrm{2,4-D} \mathrm{dan} 2 \mathrm{mg} / \mathrm{L}$ kinetin. Ini dapat dikatakan bahwa media pertumbuhan MS dengan penambahan zat pengatur tumbuh dapat mempercepat pertumbuhan tunas pada anggrek. Setiap spesies tanaman memiliki konsentrasi optimum yang berbeda, baik untuk tunas maupun $p l b$.

Tabel 5. Rata-rata pertumbuhan $(\mathrm{cm})$

\begin{tabular}{cllllllllll}
\hline MS0 & D2K1 & D2K2 & D4K1 & D4K2 & D6K1 & D6K2 & D8K1 & D8K2 & D10K1 & D10K2 \\
\hline 0,33 & 0,2 & 0,3 & 0,5 & 0,75 & 0,62 & 0,067 & 0,3 & 0,4 & 0,2 & 0,23 \\
& & & & & & & & & & \\
\hline
\end{tabular}


Tabel 6. Hasil Uji ANOVA

\begin{tabular}{cccccc} 
Panjang & $\begin{array}{c}\text { Sum of } \\
\text { Squares }\end{array}$ & df & $\begin{array}{c}\text { Mean } \\
\text { Square }\end{array}$ & F & Sig. \\
\hline $\begin{array}{c}\text { Between } \\
\text { Groups }\end{array}$ & 1.236 & 10 & .124 & 1.775 & .126 \\
$\begin{array}{c}\text { Within } \\
\text { Groups }\end{array}$ & 1.532 & 22 & .070 & & \\
Total & 2.768 & 32 & & & \\
\hline
\end{tabular}

Berdasarkan hasil dari uji ANOVA pada tabel 5. untuk data pertumbuhan panjang menunjukkan angka 0.126 pada nilai signifikansinya. Ini berarti nilai signifikansi $\geq 0,05$ berarti tidak beda nyata. Hal ini menunjukkan bahwa perbedaan jenis media tidak berpengaruh nyata terhadap pertumbuhan panjang $\mathrm{plb}$ dan tunas yang terbentuk.

\section{KESIMPULAN}

Pemberian kombinasi hormon 2,4-D dan kinetin tidak berpengaruh nyata terhadap pertumbuhan panjang plb dan tunas yang terbentuk. Konsentrasi kombinasi zat pengatur tumbuh untuk pembentukan tunas adalah $4 \mathrm{mg} / \mathrm{L}$ 2,4-D + $2 \mathrm{mg} / \mathrm{L}$ kinetin. Konsentrasi kombinasi zat pengatur tumbuh untuk pembentukan plb adalah 0- $4 \mathrm{mg} / \mathrm{L} 2,4-\mathrm{D}+0-2 \mathrm{mg} / \mathrm{L}$ kinetin.

\section{DAFTAR PUSTAKA}

Abbas, B., Listyorini, F.H., and Amriati, B. (2011). In vitro seeds germination and plantlets development of Grammatophyllum scriptum Lindl. (Orchidaceae). International Research Journal of Plant Science 2(5): 154159. 
Abidin, Z. (1985). Dasar-dasar Pengetahuan tentang Zat Pengatur Tumbuh. Bandung: CV. Angkasa.

Dorusposari, B. (2003). Pengaruh Zat Pengatur Tumbuh Kinetin dan Naphtalene Asetic Acid terhadap Pembentukan dan Perkembangan Meristem Ujung Batang Tanaman Anggrek Hibrida Phalaeonopsis "Star of Rio" secara in vitro.Skripsi.Fakultas Biologi UGM Yogyakarta.

Fitrianti, A. (2006). Efektivitas Asam 2,4-Diklorofenoksiasetat (2,4-D) dan Kinetin pada Medium MS dalam Induksi Kalus Sambiloto dengan Eksplan Potongan Daun. Semarang : UNNES.

Gunawan, L.W. (1988). Teknik Kultur Jaringan Tumbuhan. Bogor: Laboratorium Kultur Jaringan Tumbuhan Pusat Antar Universitas (PAU) Bioteknologi IPB.

Kalimuthu, K., R. Senthilkumar, and S. Vijayakumar. (2007). In vitro Micropropagation of Orchid Oncidium sp. (Dancing Dolls). African Jurnal of Biotechnology 6(10): 1171-1174.

Meyer, J.L.S., G.C. Stancato and B. Appezzato-Da-Gloria. (2010). Direct Regeneration of Protocorm-like Bodies (PLBs) from Leaf Apices of Oncidium flexuosum Sims (Orchidaceae). Plant Cell Tissue Organ 103: 411-416.

Ng, C., N. M. Saleh and F.Q. Zaman. (2010). In Vitro Multipication of the Rare and Endangered Slipper Orchid, Paphiopedilum rothschildianum (Orchidaceae). African Journal of Biotechnology. 9(14): 2062-2068

Smith, R.H. (1992). Plant Tissue Culture: Technique and experiments. New York: Academic Press Inc.

Sulistiarini, D. (2008). Keanekaragaman Jenis Anggrek Pulau Wawonii. Berk. Penel. Hayati 14: 21-27.

Sutriyan, Y. (1992). Pengantar Anatomi Tumbuh-tumbuhan tentang Sel dan Jaringan. Jakarta: PT Rineka Cipta.

Wijayani, Y., Solichatun, W. Mudyantini. (2007). Pertumbuhan Tunas dan Struktur Anatomi Protocorm Like Body Anggrek Grammatophyllum scriptum (Lindl.) Bl. Dengan Pemberian Kinetin dan NAA. Bioteknologi. 4(2): 33-40.

Zulkarnain. (2009). Kultur Jaringan Tanaman. Jakarta: Bumi Aksara. 